\title{
Sodium/Glucose Cotransporter 2
}

National Cancer Institute

\section{Source}

National Cancer Institute. Sodium/Glucose Cotransporter 2. NCI Thesaurus. Code C119006.

Sodium/glucose cotransporter 2 ( $672 \mathrm{aa}, \sim 73 \mathrm{kDa}$ ) is encoded by the human SLC5A2 gene. This protein is involved in sodium/glucose symport. 